\title{
The Experience of Trade Liberalisation in Pakistan
}

\author{
ASHFAQUE H. KHAN
}

\section{INTRODUCTION}

Trade policies in developing countries have been at the centre-stage of analysis for the past several decades. The desire for rapid economic growth in developing countries raised many question about the relationship between trade and growth [Krueger (1997a)]. It is, by now, well-established that there exists a strong positive relationship between export growth and overall economic growth in general and manufactured export growth and overall economic growth in particular. ${ }^{1}$ Those countries that have been most successful in expanding their manufactured exports have not only achieved higher economic growth but also succeeded in alleviating poverty. ${ }^{2}$ This has indeed been the case in East Asia [ADB (1997)]. The core question therefore is: which trade strategies have enabled countries to expand exports in general and manufactured exports in particular?

Pakistan's exports have fluctuated widely during the past 50 years. Exports received limited or no attention during the 1950s and as such registered an average decline of 5.7 percent per annum. Exports recovered in the 1960s and grew at an average rate of 10.7 percent per annum. The 1970s witnessed an acceleration in export growth when it grew at an average rate of 22.3 percent. The $1980 \mathrm{~s}$ and the first eight years of the 1990s exhibited a marked slow down in export growth as compared with the 1970s. In fact, exports grew by 8.5 percent per annum in the $1980 \mathrm{~s}$ and 7.6 percent per annum in the first eight years of the 1990s.

When viewed against the experiences of many successful developing countries Pakistan's export performance has been lackluster at best. In particular, the performance of manufactured exports has been quite dismal. A comparison of the performance of Pakistan's manufactured exports with those of 10 other developing countries clearly points out the weaknesses of the trade regime followed in Pakistan Islamabad.

Ashfaque H. Khan is Economic Adviser to the Ministry of Finance, Government of Pakistan, Author's Note: The views expressed in the paper are those of the author alone and do not necessarily represent those of the Ministry of Finance.

'See ADB (1997); Khan and Saqib (1993) and Khan et al. (1995).

${ }^{2}$ See Chen et al. (1994) and Deininger and Squire (1996). 
over the last five decades. In 1965, Pakistan's manufactured exports ( $\$ 0.19$ billion) exceeded the combined total of such exports from Indonesia, Philippines, Thailand, Turkey and Malaysia (see Table 1). After five years (1970), the combined manufactured exports of these countries were almost equal to that of Pakistan's. By 1993, the manufactured exports of each of these countries exceeded those of Pakistan by a wide margin and by 1996 Pakistan's comparison with these countries became redundant. Interestingly, Pakistan's manufactured export even exceeded those of Brazil and Korea in 1965 but stood at $\$ 7.3$ billion in 1996 as against $\$ 25.5$ billion and $\$ 114.4$ billion in the case of these two countries, respectively.

Table 1

Manufactured Exports of Major Developing Countries, 1965-96

\begin{tabular}{lcccccc}
\hline Countries & 1965 & 1970 & 1985 & 1990 & 1993 & 1996 \\
\hline Pakistan & 0.19 & 0.4 & 1.73 & 3.2 & 5.6 & 7.3 \\
India & 0.83 & 1.1 & 5.89 & 13.5 & 16.2 & 23.9 \\
China & - & 1.0 & 13.38 & 44.6 & 74.3 & 126.9 \\
Indonesia & 0.027 & 0.01 & 2.36 & 9.6 & 17.8 & 25.4 \\
Philippines & 0.043 & 0.1 & 2.53 & 5.4 & 8.5 & 17.0 \\
Thailand & 0.03 & 0.1 & 2.58 & 11.3 & 26.9 & 40.7 \\
Turkey & 0.011 & 0.1 & 3.85 & 10.3 & 11.0 & 17.0 \\
Brazil & 0.134 & 0.4 & 8.91 & 16.0 & 23.2 & 25.5 \\
Malaysia & 0.075 & 0.1 & 4.40 & 13.5 & 30.6 & 59.4 \\
Mexico & 0.165 & 0.3 & 7.13 & 12.0 & 15.7 & 74.2 \\
Korea & 0.104 & 0.6 & 27.7 & 58.7 & 77.3 & 114.4 \\
\hline
\end{tabular}

Source: World Development Reports 1987, 1990 and 1997; The World Bank, Washington, D.C.

The above analysis clearly suggests that the countries that were able to organise themselves for large scale manufactured exports chosen the right trade strategies, maintained macro-economic stability, and were able to take advantage of the expanded opportunities in developed country markets. As shown in Table 1, the countries like Thailand, Malaysia, Indonesia, Korea, Brazil and China succeeded in expanding their manufactured exports by many folds over the last three decades. Why Pakistan lagged behind in exploiting opportunities like many other developing countries in expanding exports in general and manufactured exports in particulars? A country's exports performance is the mirror image of the trade regime it has followed. It also depend on the types of trade and exchange rate policies it has pursued over the years. What trade strategy Pakistan has followed?. What type of exchange rate policy has been pursued? What export promotion measures have been taken? What has been happening on the macro-economic stability front? What is the 
state of human and physical infrastructure? These are relevant questions which need to be answered while analysing Pakistan's exports. This article is, however, only concerned with the trade strategy that Pakistan has followed while answer to the rest of the questions and much more can be found in Khan (1998).

In this article we review the trade strategy followed in Pakistan over the last 5 decades with major emphasis on the post-1980 developments on trade liberalisation. In other words, attempt is made to document the trade liberalisation measures undertaken over the years with a view to reducing anti-export bias. The plan of the paper is as follows: In Section II we present an overview of the trade regime where we discuss import substitution versus export promotion and their pros and cons in terms of increasing exports. Section III discusses the trade regime in the context of Pakistan's experience and also documents the trade liberalisation measures undertaken over the years to make a shift away from one regime to the other. Concluding remarks are presented in the final section.

\section{AN OVERVIEW OF THE TRADE REGIME}

Trade strategy can broadly be classified into import substitution (inward oriented) and export promotion (outward oriented). Import substitution (IS) is associated with a package of policies that aim at protecting the infant industries and discriminating against exports. Such policies include overvalued exchange rate, multiple exchange rate system, import controls, high tariffs and quantitative restrictions on imports [Krueger $(1997,1978)$ ]. These measures discriminate against exports because they force exporters to face import prices that are above the international level for the inputs they want. Furthermore, in the IS strategy production for the domestic market to satisfy internal demand under the protection of tariff and non-tariff barriers is favoured over the export market. The export promotion $(E P)$ strategy, on the other hand, is one in which trade and industrial policy do not discriminate between production for the domestic market and exports. This strategy links the domestic economy to the world economy.

Some more clarification regarding the $E P$ strategy are in order. Firstly, the definition of $E P$ strategy relates to average incentives [Krueger (1997a)]. It is perfectly valid to exist IS strategy in the sense that the effective exchange rate for import $\left(E E R_{m}\right)$ is greater than the effective exchange rate for export $\left(E E R_{x}\right)$ in some activities even within the overall $E P$ strategies. The $E P$ strategy can co-exist with IS strategy in some sectors as has been the case in many successful East Asian countries. Secondly, the EP strategy does not imply the absence of government intervention. In many East Asian countries, the EP strategy worked along side with

${ }^{3}$ See World Development Report 1987.

${ }^{4}$ It may be noted that the $E P$ strategy and 'export-led' growth have often been misunderstood as one of the same thing in the literature. As Bhagwati $(1987$, p. 258) has pointed out, the EP strategy has "little to do with export-led growth". In fact, it is simply "a matter of setting price incentives in such a fashion as to ensure that the home does not become more lucrative than the foreign market". 
active government intervention. Thirdly, the $E P$ strategy relates to trade incentives, therefore, the countries that follow this strategy not necessarily be outward oriented in their foreign investment policies. Once again, the East Asian countries and Japan provide clear evidence in this regard.

In the classic NBER study, Krueger (1978) and Bhagwati (1978) have defined trade orientation in terms of the $E E R_{x}$ relative to that of $E E R_{m}$. These effective exchange rates measure the incentives to export and to substitute for exports, respectively. The $I S$ strategy is the one where $E E R_{x}$ is less than $E E R_{m}\left(E E R_{x}<E E R_{m}\right)$. This strategy, on balance, rewards production for the domestic market more than for exports, or in other words, there is a 'bias' in favour of imports. A formal index of the degree of bias is defined as the ratio of the exchange rate effectively paid by importers $\left(E E R_{m}\right)$ to the exchange rate effectively faced by exporters $\left(E E R_{x}\right)$. If $E E R_{m} / E E R_{x}>1$ it is said that the trade regime is biased against exports [Bhagwati (1988) and Edwards (1993)]. The EP strategy is defined in the literature as the one with bias-free incentives, i.e., the one with $E E R_{m} \approx E E R_{x}{ }^{5}$ No bias or neutrality means that incentives are neutral between saving a unit of foreign exchange through import substitution and earning a unit of foreign exchange through exports. ${ }^{6}$

The effective exchange rate pertains to the combined effect of exchange and trade policies on relative prices. More specifically, the $E E R_{x}$ includes the nominal exchange rate $\left(e_{R}\right)$ as well as export subsidy $(s)$ and other incentives to exports $(k)$. That is:

$$
\begin{array}{llllllll}
E E R_{x}=e_{R}(1+s+k) & \ldots & \ldots & \ldots & \ldots & \ldots & \ldots
\end{array}
$$

Similarly, the $E E R_{m}$ would add to the nominal exchange rate $\left(e_{R}\right)$ the import tariff $(t)$, import premiums resulting from quantitative restrictions (pr) and other import charges $(q)$. That is:

$$
\begin{array}{llllllll}
E E R_{m}=e_{R}(1+t+p r+q) & \ldots & \ldots & \ldots & \ldots & \ldots & \ldots
\end{array}
$$

Thus, as long as export subsidy and other incentives to exports more or less match the import duty, import premium and other import charges, there will be no bias against exports. ${ }^{7}$ Hence the degree of bias of the trade regime is measured as

$$
\beta=\frac{E E R_{m}}{E E R_{x}}=\frac{e_{R}(1+t=p r+q)}{e_{R}(1+s+k)} \quad \ldots \quad \ldots \quad \ldots \quad \ldots \quad \ldots
$$

${ }^{5}$ Bhagwati (1988) defines ultra-EP strategy as the one with $E E R_{x}>E E R_{m}$.

${ }^{6}$ For further discussion on this see Bhagwati $(1988,1978)$ and Krueger $(1978)$.

${ }^{7}$ Macroeconomists have defined effective exchange rate by simply deflating the nominal exchange rate (i.e. parity) by the domestic price level. Bhagwati (1987) has termed this definition inadequate because in many developing countries import duties, subsidies and other charges are important and concentrating on the parity alone is not enough. He has, therefore, recommended the concept of pricelevel deflated EER (PLDEER) propounded by Bhagwati (1978) and Krueger (1978) that the macroeconomist should use. 
where $\beta=1$ reflects the existence of a neutral trade regime while $\beta>1$ represents the fact that the country in question is following the IS strategy or in other world, pursuing a policy which promotes anti-export bias.

Based on the intellectual support provided by Nurkse (1961) and Prebisch $(1950,1959)$ a broad consensus was emerged in developing countries during the early years that trade strategy for development should be based on import substitution $(I S)$. The basic motivation underlying IS strategy was the belief that industrialisation would be possible only in a protected closed market. The stylised facts that encouraged developing countries to adopt the IS strategy in the early years are numerous which ranged from their relative backwardness, lack of competitive strength to what is commonly know as export pessimism. ${ }^{8}$

Firstly, the developing countries' production structure were heavily oriented towards production and exports of primary commodities and the ability to produce manufactured goods were virtually non-existent. In such an environment a policy of free trade would had confined them in the production of primary commodities because of their comparative advantage in them. It was, therefore, realised that industrialisation and, hence, development would only be possible under the import substitution strategy. This provided a strong argument in favour of developing productive capacities at home to replace imports from abroad. As such industry needed protection at the early stages of development.

Secondly, the export pessimism was based on the premise that not only the income and price elasticities of demand for primary commodities were low but the terms of trade was also deteriorating against primary commodities. As such, the developing countries exports were to grow only slawly. Furthermore, under what is generally known as 'second export pessimism', there was a common belief that exports from developing countries cannot successfully penetrate the restrictive barriers of the developed economies [Bhagwati (1988)]. ${ }^{9}$ Thus, IS became the hallmark of development strategies in many developing countries.

The above factors underlying $I S$ strategy were so convincing that developing countries were accorded exception in the General Agreement on Tariffs and Trade (GATT) Articles. In fact, Article XVIII explicitly protected developing countries and allowed them to adopt tariffs and quantitative restrictions to protect their domestic industries [Krueger (1997)]. Such exception not only legitimised the type of trade strategy followed by developing countries but also allowed them to postpone much needed trade and payment reform more conducive to sustained economic growth [Krueger (1997)].

${ }^{8}$ For a detailed discussion on the stylised facts, see Krueger (1997a).

${ }^{9} \mathrm{~A}$ recent World Bank study estimates that non-tariff barriers (NTBs) in the major industrial countries affect 34 percent of imports from developing countries, as opposed to 27 percent from all countries, and that in the early 1980 NTBs in the developed countries became significantly more extensive. For further discussion see Nognes et al. (1985). 
At the very early stages of development the IS strategies are, however, not necessarily inimical to growth. Import substitution did help to produce high rates of GDP growth in many developing countries. However, the ability to sustain high rate of growth weakened over time under this strategy [Krueger (1997a)]. The crucial feature of good economic management was not to prolong the IS strategy beyond the initial stage of development and effort should have been made to remove anti-export bias fairly quickly so that, on balance, the divergence between $E E R_{x}$ and $E E R_{m}$ was narrowed. It was soon revealed that the $I S$ strategy suffered from some major shortcomings.

Firstly, it was found that import substitution often increased, rather than reduced a country's dependence on foreign exchange. This is because sufficient disincentives were provided for export development under the $I S$ strategy. As $I S$ strategy proceeded long enough many developing countries that have followed this strategy encountered increasingly severe foreign exchange shortages [Krueger (1984)].

Secondly, the overvalued exchange rate goes hand-in-glove with import substitution because the authorities, under pressure from producers, maintain an unrealistic real exchange rate so as to keep the costs of imported inputs and capital equipment low. Periodic balance of payments crisis arose in reaction to overvalued exchange rate which adversely affected a country's export earnings.

Thirdly, the availability of cheaper capital and duty-free imports of capital goods to encourage import substitution created a capital-intensive bias in production, which made it difficult to absorb excess unskilled labour in modern industry. At the same time, high-cost capital-intensive production raised incremental capital output ratios (ICORs) under continuing import substitution, requiring ever-increasing saving ratios to maintain rates of economic growth. Fourthly, the IS strategy encouraged smuggling ${ }^{10}$ and fake invoicing to import lower-cost products [Krueger (1997a)]. Fifthly, tariff barriers and quantitative restrictions which are salient features of the IS strategy created artificial scarcity and helped create active black markets for imported goods [Reza (1994)]. Finally, under the IS strategy the real interest rate often kept negative to favour import substituting investments. In the process, the negative real interest rate policy discouraged domestic savings, encouraged self-investment, and provided inducements for the transfer to funds abroad. ${ }^{11}$

It is widely accepted that under $I S$ strategy, any success is short-lived. ${ }^{12}$ An important question, then, is why export orientation is a better policy. An outwardoriented trade strategy is recognised to have a number of advantages. Firstly, this

\footnotetext{
${ }^{10}$ If the price differential between the domestic market and the international market is sufficiently wide either as a result of higher tariff or legally-binding quota, smuggling would be profitable [Krueger (1984)].

${ }^{11}$ More on this, see Balassa (1985).

${ }^{12}$ See for example, Krueger $(1978,1981,1997,1997 a)$ and Bhagwati $(1978,1987)$.
} 
strategy brings incentives for domestic resource allocation closer to international opportunity costs and hence, promotes the efficient use of resources. Secondly, export-orientation is a better policy because it involves incentives rather than controls. The rationing of import licenses, credit, and foreign exchanges has invariably generated premiums and, in turn, rent seeking under the $I S$ strategy.

Thirdly, export-orientation gives industries the opportunity to enlarge their markets and achieve greater economies of scale. In other word, in an outwardoriented regime, the size of the domestic market does not limit the output of exporting firms [Krueger (1981)]. Fourthly, an outward-oriented strategy forces industries to compete in the international market and achieve greater $\mathrm{X}$-efficiency [Balassa (1981)].

Fifthly, there is increasing evidence that adoption of new technology has been faster in outward-oriented than in inward-oriented (or $I S$ ) developing countries. Exporting firms often benefit from a considerable transfer to technology from abroad, including advice on production engineering and aid in product design and marketing [ADB (1997)].

Sixthly, outward-oriented regime provides self-correcting mechanism to align the macroeconomic variables that affect growth. For example, if the exchange rate is overvalued it will become obvious quickly because trade balance will deteriorate. Under IS strategy the effect of the misalignment in exchange rate would take the subtler form of rising premiums on import licenses. Finally, it is well-known that outward-oriented economies have achieved spectacular growth in saving rates [ADB (1997)]. A shift from inward to outward orientation should generate additional real income, partly by reducing the misallocation of resources and partly by raising income through multiplier effects as rising exports bring spare capacity into use.

Thus, the superiority of the outward-oriented strategy over the IS strategy is no longer an issue in development economics. Countries that pursued outwardoriented strategy between 1965 and 1990 grew about 2 percentage points faster per year, on average, than countries that pursued $I S$ strategy. ${ }^{13}$ The East and Southeast Asian countries were the ones that followed vigorously the outward-oriented strategy which helps to account for their better growth performance. Following at the initial stage a modest IS strategy, most of the fast growing Asian countries lowered their import tariffs and export taxes, removed quantitative restrictions on trade, and reduced barriers to international flows of capital. They also ensured high profitability for their exporters of manufactured goods by giving them easy access to inputs at world prices and followed prudent exchange rate policies. In other word, they quickly moved to outward-oriented strategy, maintained macroeconomic stability and pursued prudent exchange rate policies. Such a shift in the strategy and other macroeconomic policies paid rich dividends in terms of higher sustained economic growth which became the hallmark of the East and Southeast Asian countries. The

\footnotetext{
${ }^{13}$ See ADB (1997).
} 
poor performance of the Latin American and South Asian countries, most of which had followed with almost religious zeal the dictates of import substitution, offered a dramatic contrast.

\section{TRADE REGIME: THE PAKISTANI EXPERIENCE}

Attempt is made in this section to review the trade regimes Pakistan has followed over the last five decades. A review of the trade regimes followed in Pakistan during the 1950s, 1960s, 1970s, and to some extent 1980s are welldocumented in Guisinger and Scully (1991); Naoman (1992) and Shah et al. (1990). Thus, no effort is made to present an in-depth review of the trade regimes for these periods with the exception of the 1980s. Major emphasis is, however, given to the developments in trade liberalisation with a view to reducing anti-export bias since 1980. However, to appreciate the trade liberalisation efforts undertaken in Pakistan since the 1980s it is essential that we review, though briefly, the trade regimes followed in the country during the 1950s, 1960s, and 1970s.

The choice of a trade regime depend partly on the resource endowment of the country. At the time of independence in 1947 Pakistan's industrial base was confined to a few textile mills, some sugar mills and some cement factories, all totalling 34 units. It was considered essential for the country to provide adequate protection to the nascent local industry against imports. As such Pakistan's economic policy emphasised import substitution during the early years of independence, although efforts were also made to promote exports.

\section{The 1950s}

During the 1950 s, Pakistan pursued IS strategy vigorously, thereby creating a highly protected environment for industrialisation. Quantitative restrictions on imports and other non-tariff barriers have been the principal policy instruments to cope with the balance of payments crisis at the end of the Korean war-related commodity boom in 1952. The import restrictions have allowed the country to maintain an overvalued exchange rate which, in turn, has been used to subsidise the inflow of imported inputs into priority areas. Furthermore, as indicated above, Pakistan inherited very little industry but more agricultural resources. ${ }^{14}$ The tax and other incentive structure that evolved was such that revenue depended heavily on export taxes on agricultural products (Cotton and Jute) and import duties on imported manufactured goods. The policy incentives were designed in such a way that domestic producers of manufactures used to buy domestic agricultural raw materials at below world prices and used to sell their products domestically at above world prices. This resulted into a large protection of import substitutes and a tax on

\footnotetext{
${ }^{14}$ Agriculture accounted for 48 percent, 40.4 percent, and 33.5 percent of GDP in the 1950s, 1960 s, and 1970s; respectively.
} 
exports. ${ }^{15}$ Thus, the most extreme form of protection lasted from 1952 to 1959 [Naoman ((1992)].

\section{The 1960s}

While maintaining a highly protective and restrictive import regime and an overvalued exchange rate to promote import substitution during the 1950s, the government began to promote export growth by taking a number of measures to reduce the anti-export bias of the trade regime during the 1960s. Firstly, the government introduced the export bonus scheme in the late 1959, which was in effect a multiple exchange rate system favouring manufactured exports. ${ }^{16}$ Secondly, industries with export potential were singled out for special treatment such as preferential access to foreign exchange. ${ }^{17}$ Thirdly, a significant import liberalisation was under taken. The major liberalising policy adopted in this period was the automatic renewal of import license for industrial raw materials and consumer goods. While selecting firms for automatic renewal of licences their previous export performance was taken into consideration [Guisinger and Scully (1991)]. Those firms with best performance in exports received the best liberal treatment insofar as licenses were concerned; the less favoured firms had to show proof of export orders before import licenses necessary for export production could be released. Another major liberalisation policy of the 1960s include the free list of imported items. Almost all the requirements of industries for imported raw materials and spares were placed on the free list; the funds for which were made available through the Pakistan Consortium. ${ }^{18}$

Despite these measures to reduce anti-export bias, the degree of trade liberalisation was fairly marginal. For example, the coverage of the export bonus scheme was very small (about 5 percent of total imports). Furthermore, the liberalisation were discriminatory in nature, partly because of the piecemeal implementation of the reforms. ${ }^{19}$

Although the large-scale manufacturing grew at an average rate of 13.4 percent per annum during the 1960 s and was widely hailed as a model of successful industrialisation it was also regarded as one of the worst examples of import substituting industrialisation by Little, et al. (1970) and Balassa (1971). The export bonus scheme which was tailored to provide greater incentives to exporters of

${ }^{15}$ More on this, see DRI-McGraw Hill (1997).

${ }^{16}$ Export Bonus Scheme (EBS) was by far the most important policy initiative taken by the government to reduce anti-export bias of the trade regime. Since the EBS was in effect a multiple exchange rate system it served as an instrument to compensate exporters of selected manufactured commodities for the overvaluation of the rupee. For a detailed discussion on EBS, see Guisinger and Scully (1991).

${ }^{17} \mathrm{~A}$ host of other incentives for exports were also provided. See Guisinger and Scully (1991) for details.

${ }^{18}$ The free list was not quite as liberal as its name implies. Import duties on free-list imports were increased from 5 to 20 percent. For further details, see Guisinger and Scully (1991).

${ }^{19}$ See ibid. 
manufactured goods was instrumental in increasing the manufactured exports by 11.4 percent per annum in current rupee term during the 1960 s as against 1.8 percent growth of primary exports and 7.0 percent growth of total exports. Consequently, the share of manufactured exports in total exports increased from 43 percent in 1960 to 67 percent in 1970 .

\section{The 1970s}

During the 1970s, three most significant measures of trade liberalisation to reduce anti-export bias were taken. These measures were: devaluation, the elimination of the export bonus scheme, and the end of restrictive licensing. As a result of the fixed exchange rate policy, Pakistani rupee was overvalued during the 1950 s and the 1960s which encouraged import substitution. The export bonus scheme of the 1960s was meant to compensate exporters of selected manufactured items from this overvaluation. The May 1972 devaluation of 57 percent was accompanied by the elimination of the export bonus scheme. The decision to eliminate the scheme was a movement toward more uniform effective exchange rates for exports. The third important measures was to cut down the restrictive licensing system in 1972. The six separate import lists were reduced to only two lists-a free list of items which, in principle, could enter the country without restriction and a tied list of items importable only from tied aid or barter sources.

The above listed trade liberalising measures along with fairly successful efforts of the Pakistani exporters to divert their exports from the protected markets of the former East Pakistan (now Bangladesh) to the world market in the early 1970s led to an impressive increase in manufactured exports (manufactured exports increased at the compound growth rate of 26 percent per annum in current rupee term). Notwithstanding massive devaluation, elimination of the export bonus scheme, and sharply curtailed licensing system, the overall trade and industrial policies remained biased against exports during the 1970s. This fact is abundantly clear from Table 2 and Figures 1 and 2. The existence of an anti-export bias is demonstrated by the quantitative evidence provided in Table 2 which presents estimates of effective exchange rates (EERs) for imports and exports and their ratios. The latter ratios can be utilised as a summary index of the neutrality/non-neutrality of a trade regime. Results of EER calculations demonstrate the existence of an import substitution bias that appears to have increased during the 1970s. The principle reason for the persistence of anti-export bias in the face of massive devaluation is that the currency devaluation was accompanied by export taxes. By October 1973 the export duties on cotton yarn reached as high as 45 percent, on grey cloth it was 25 percent, and on other finished cotton and leather products it was 15 percent. ${ }^{20}$ Thus the effective devaluation on the export side amounted to only 25 percent as against the nominal devaluation of 57 percent. $^{21}$

${ }^{20}$ See Chaudhry and Hamid (1988).

${ }^{21}$ See Guisinger and Scully (1991). 
Table 2

Effective Exchange Rates for Imports and Exports

\begin{tabular}{|c|c|c|c|c|}
\hline Year & $\begin{array}{l}\text { Effective Exchange } \\
\text { Rate for Imports } \\
\left(\mathrm{EER}_{\mathrm{m}}\right)\end{array}$ & $\begin{array}{l}\text { Effective Exchange } \\
\text { Rate for Exports } \\
\left(E^{2} R_{x}\right)\end{array}$ & $\begin{array}{c}\text { Bias } \\
\left(\mathrm{EER}_{\mathrm{m}} / \mathrm{EER}_{\mathrm{x}}\right)\end{array}$ & $\begin{array}{c}\text { Real } \\
\text { Exchange } \\
\text { Rate }\end{array}$ \\
\hline $1969-70$ & 6.00 & 4.90 & 1.22 & 4.80 \\
\hline $1970-71$ & 6.60 & 4.91 & 1.34 & 4.61 \\
\hline $1971-72$ & 14.70 & 10.64 & 1.38 & 10.39 \\
\hline $1972-73$ & 11.88 & 8.74 & 1.36 & 8.37 \\
\hline $1973-74$ & 11.68 & 8.22 & 1.42 & 8.97 \\
\hline $1974-75$ & 11.68 & 9.00 & 1.30 & 8.57 \\
\hline $1975-76$ & 12.03 & 9.33 & 1.29 & 9.72 \\
\hline $1976-77$ & 12.51 & 9.89 & 1.26 & 9.47 \\
\hline $1977-78$ & 12.84 & 9.86 & 1.30 & 9.53 \\
\hline $1978-79$ & 12.60 & 9.87 & 1.28 & 9.51 \\
\hline $1979-80$ & 12.44 & 9.91 & 1.25 & 9.33 \\
\hline $1980-81$ & $12 . .47$ & 9.90 & 1.26 & 9.28 \\
\hline $1981-82$ & 16.06 & 13.17 & 1.22 & 12.45 \\
\hline $1982-83$ & 17.47 & 14.18 & 1.23 & 12.43 \\
\hline $1983-84$ & 19.64 & 15.78 & 1.24 & 14.06 \\
\hline $1984-85$ & 20.47 & 16.73 & 1.22 & 15.82 \\
\hline $1985-86$ & 22.91 & 17.72 & 1.29 & 16.10 \\
\hline $1986-87$ & 25.37 & 18.55 & 1.38 & 16.32 \\
\hline $1987-88$ & 25.88 & 19.57 & 1.32 & 17.86 \\
\hline $1988-89$ & 28.08 & 21.46 & 1.31 & 20.38 \\
\hline $1989-90$ & 29.72 & 22.52 & 1.32 & 21.10 \\
\hline $1990-91$ & 32.52 & 25.50 & 1.27 & 22.66 \\
\hline $1991-92$ & 32.97 & 26.42 & 1.25 & 23.94 \\
\hline $1992-93$ & 38.19 & 31.77 & 1.20 & 28.34 \\
\hline $1993-94$ & 39.28 & 32.31 & 1.21 & 27.10 \\
\hline $1994-95$ & 42.33 & 34.63 & 1.22 & 29.54 \\
\hline $1995-96$ & 42.95 & 36.11 & 1.19 & 32.51 \\
\hline $1996-97$ & 49.61 & 41.25 & 1.20 & 35,80 \\
\hline
\end{tabular}




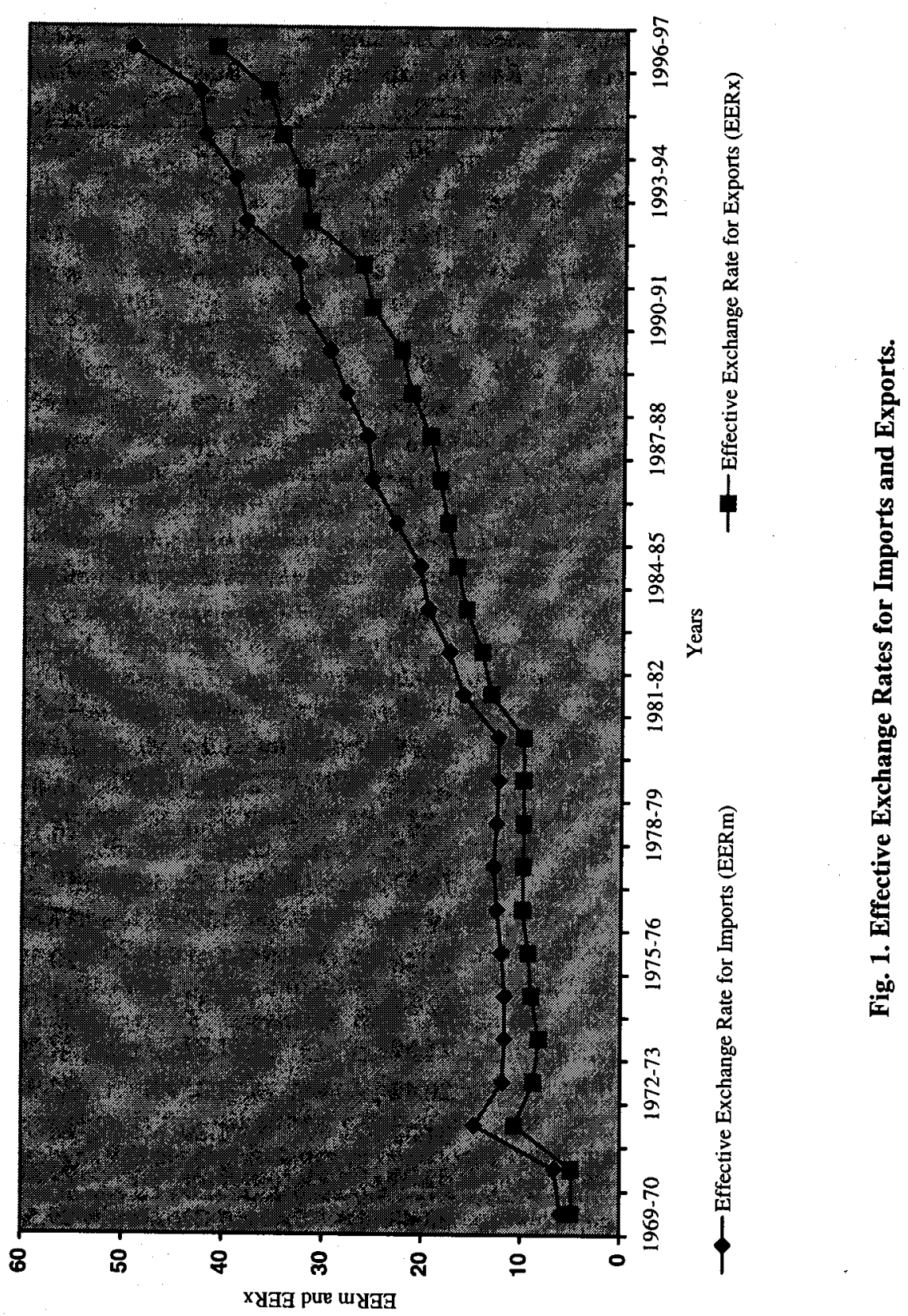




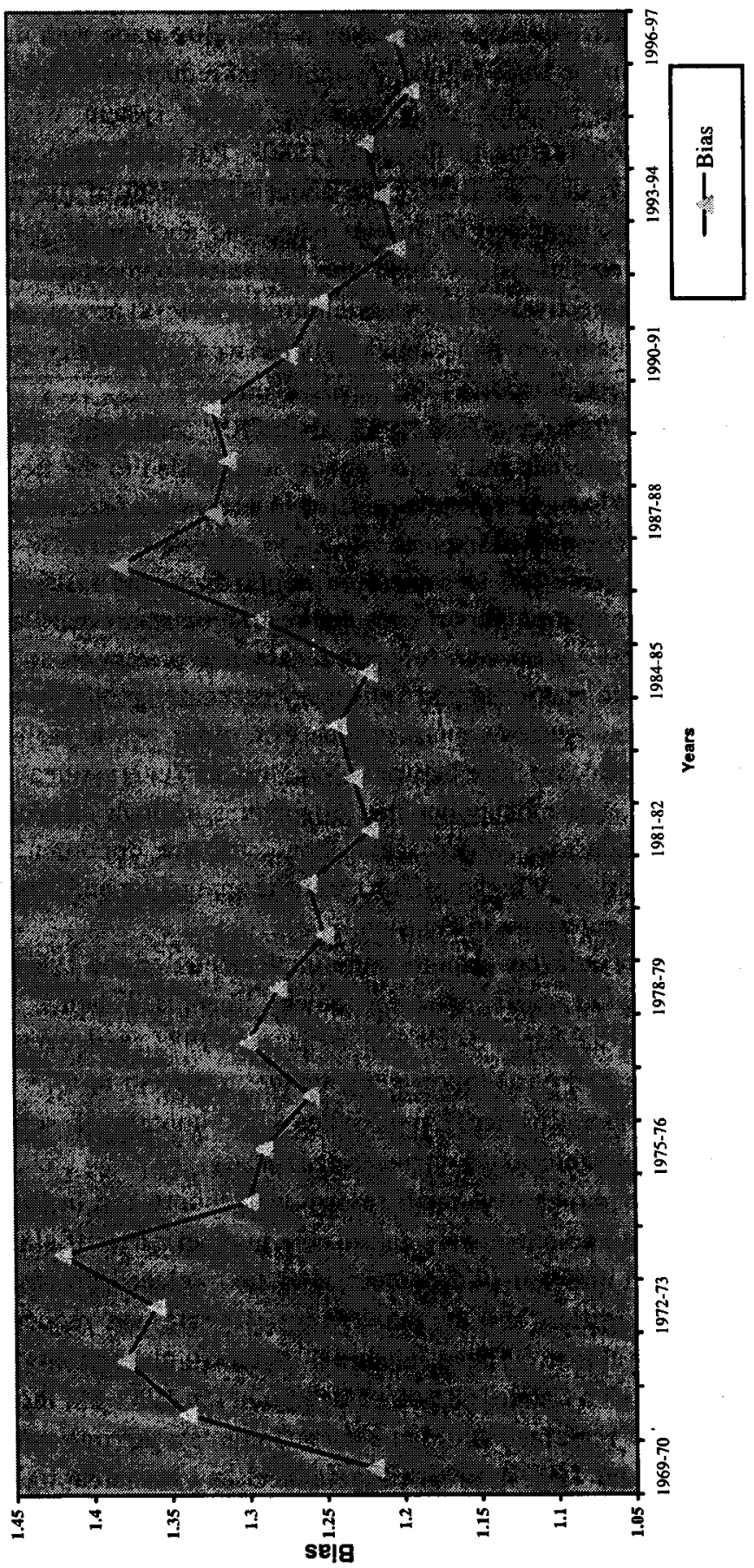

 


\section{The 1980s}

During the 1980 s, periodic steps were taken to liberalise trade with a view to reducing anti-export bias in the trade regime. A significant reduction in the scope of non-tariff barriers and the adoption of a negative import system were major improvements in the import regime in the early 1980s. Pakistan's import regime reached its most restrictive stage in 1980 when about 41 percent of the domestic industrial value added was protected by import bans, and another 22 percent by various forms of import restrictions. By 1986, the equivalent percentages were 29 percent and 3.7 percent respectively. This was achieved by two types of measures, Firstly, explicit import quotas on non-capital imports were essentially removed. Secondly, banned and restricted imports were slowly liberalised.

Between December 1980 and June 1983, about 100 commodity categories, consisting of mostly raw materials and capital goods, were added to the free list. In July 1983, the Government switched from a positive to a negative list system which explicitly listed banned and restricted imports.

Pakistan, however, continued to depend on import bans and restrictions for protection. The official position on import bans and restriction states that Pakistan's non-tariff barriers serve two purposes: to provide assured protection to importcompeting industries, and to restrict imports of luxury consumer goods. In practice, however, non-tariff barriers generate more serious distortions. As is well-known, import bans/restrictions break the link between domestic and international relative prices. Furthermore, it creates monopolies and oligopolies through elimination of foreign competition in industries where scale economics are important. Import bans/restrictions and prohibitively high tariffs have made smuggling and other forms of illegal trade a profitable enterprise in Pakistan.

A number of import tariff/tax changes were implemented in the 1980s. These included: (i) The setting of tariff rates for newly liberalised items; (ii) the introduction of a 5 percent surcharge on all imports in June 1983 (with exception of baggage allowances and parcel post) followed by another 5 percent Iqra ${ }^{22}$ surcharge imposed in June 1986; and (iii) tariff removal/cuts on imports of some noncompetiting machinery and inputs to the engineering industry.

By far the most comprehensive tariff reform was undertaken in June 1987 when most rates were cut and some were raised, the number of tariff slabs were reduced from 17 to 10 ; a uniform 12.5 percent sales tax replaced previous rates that varied across commodities; and the maximum tariff rate was reduced from 225 percent to 125 percent. These changes reduced the economy-wide (unweighted) average tariff by almost 8 percentage points in 1987-88, though the dispersion of tariffs has remained the same (see Table 3). Among the major commodity categories, the largest proportionate decline was in capital goods.

\footnotetext{
${ }^{22}$ Surcharges to generate funds for education.
} 
Table 3

Average Level and the Dispersion of Statutory Tariffs

\begin{tabular}{|c|c|c|c|c|c|c|c|c|}
\hline \multirow[b]{3}{*}{ Tariff } & \multicolumn{2}{|c|}{ Early $1980 \mathrm{~s}$} & \multicolumn{2}{|c|}{$1987-88$} & \multicolumn{2}{|c|}{$1988-89$} & \multicolumn{2}{|c|}{$1989-90$} \\
\hline & $\overline{\text { Mean }}$ & Standard & $\overline{\text { Mean }}$ & $\mathrm{SD}$ & $\overline{\text { Mean }}$ & $\overline{\mathrm{SD}}$ & Mean & $\overline{S D}$ \\
\hline & & Deviation & & & & & & \\
\hline Economy-wide & 77.1 & 52.6 & 68.9 & 52.2 & 66.3 & $\overline{41.4}$ & 64.8 & $\overline{41.4}$ \\
\hline Manufacturing & 79.1 & 53.0 & 70.9 & 52.7 & 67.6 & 41.7 & 66.0 & 41.7 \\
\hline Consumer Goods & 116.7 & 57.9 & 98.1 & 53.9 & 97.0 & 40.3 & 96.6 & 40.2 \\
\hline International Goods & 61.3 & 40.2 & 65.4 & 48.3 & 57.2 & 27.6 & 53.9 & 26.8 \\
\hline Capital Goods & 66.5 & 43.6 & 39.3 & 35.7 & 37.6 & 35.7 & 37.4 & 35.4 \\
\hline
\end{tabular}

Source: Government of Pakistan, Central Board of Revenue, Pakistan.

Customs Tariff and Allied Notifications and Orders, Islamabad (various editions).

The economy-wide (unweighted) average tariff was further reduced to 64 percent in 1989-90. The improvement (i.e. the fall) in the dispersion was more pronounced as it was reduced by almost 11 percentage points (See Table 3 ).

Notwithstanding the June 1987 tariff changes, Pakistan's average (nominal) tariff rates were still high in comparison to other developing countries. About 50 percent of all tariff categories, and 84 percent of consumer goods carry custom duties in excess of 75 percent. The effects of high customs duties on landed costs of imports were compounded further by surcharges and the sales tax.

Another notable feature of Pakistan's nominal tariff structure was the substantial number of duty free categories and full partial duty exemptions. Such feature narrow the import tax base, leading to a concentration in the incidence of tariff, cause discriminations and anomalies in the implementation of the tariff system and induce rent-seeking activities. Nearly 80 percent of all import duties were collected from 21 commodity groups that account for less than half of the total value of imports.

In the 1980s, a shift from fixed to a flexible exchange rate system was by far the most important measure undertaken to encourage export growth. In addition, since the late 1970s there has been a continuous effort to improve the effectiveness of some of the existing export incentive schemes-namely, the duty drawback system, compensatory export rebates (which was abolished in May 1986), and concessionary export financing. The Government's continued emphasis on export promotion was also reflected in some positive measures introduced through the New Trade Policy in June 1987. These included: (i) opening of rice and cotton exports to the private sector; (ii) liberalisation of imports of some raw materials and intermediate inputs of export industries; (iii) establishment of a Special Credit Wing for exporters at the State Bank of Pakistan; (iv) the provision of foreign exchange to promote marketing of goods abroad; (v) linking income tax concession on export 
earnings to the value-added content of exports; and (vi) the introduction of a valueadded criterion in the allocation of textile export quotas in addition to historical performance criteria. ${ }^{23}$

Notwithstanding significant trade reform introduced in the $1980 \mathrm{~s}$, the existence of an anti-export bias is demonstrated by the quantitative evidence provided in Table 2. Results of EER calculations demonstrate the existence of an import substitution bias that appears to have increased over time during the 1980s. In particular, the bias increased significantly after the trade liberalisation measures introduced in June 1987. The reduction in the bias achieved through tariff cuts has been more than offset by the imposition of import surcharges, and the elimination of compensatory rebates in May 1986. In sum, Pakistan's trade regime remained bias in favour of import-substituting production in the 1980s.

\section{Onwards}

Despite various measures of trade liberalisation undertaken during the 1980s Pakistan's trade regime remains protective and continues to discriminate against exports. Pakistan embarked on a comprehensive programme of macroeconomic adjustment and structural reform at the end of 1980s. The trade reform is viewed as a primary instrument of structural reform because of the realisation that past import-substitution policies had insulated the country from foreign competition and generated a strong anti-export bias in resource allocation and increased inefficiency. Towards this end, successive governments since 1988 have pursued an extensive liberalisation of the trade regime and also undertaken a range of export promotion measures. As a result, almost all non-tariff barriers have been replaced with tariffs; the maximum level of tariffs has been reduced to 45 percent in 1997-98 from 225 percent in 1986-87; the earlier para-tariffs have been merged into the statutory tariff regime; efforts have been made for suitable cascading the tariff structure; and all items are now importable except for a few whose entry is conditional on religious, health or security considerations. ${ }^{24}$

Although successive governments have pursued tariff reform programmes since 1988 with an aim to reduce anti-export bias, with varying degree of success, the caretaker government in 1993 however produced a comprehensive document on tariff reform. The Tariff Reform Committee of 1993 proposed a wide-ranging programme of tariff reduction, consolidation, and suitable cascading. The Committee recommended two alternatives in setting the maximum tariff rate. The first alternative was directed more towards reducing the bias against exports by setting a maximum tariff rate of 35 percent for most products with a few exceptions (chemical and engineering) of 50 percent. The second alternative set the maximum rate at 50 percent for all items except automobile (265 percent).

\footnotetext{
${ }^{23}$ For a detailed discussion on these measures, see the New Trade Policy, June 1987, Ministry of Commerce, Government of Pakistan.

${ }^{24}$ For further discussion, see Khan and Mahmood (1996) and DRI-McGraw Hill (1997).
} 
The Tariff Reform Committee of 1993 recommended that: (i) all para-tariffs such as import license fee ( 6 percent), Iqra surcharge ( 5 percent), and flood relief surcharge ( 1 percent), be merged with the statutory tariff rates, (ii) the current maximum tariff rate of 80 percent be reduced following either of the two alternatives mentioned above with six tiers of ad valorem rates; (iii) nominal tariffs be suitably cascaded with rates increasing with progressive stages of manufacturing; (iv) zerorated inputs for export-oriented production; (v) tariffs on machinery and equipment would be 10 percent, unless locally available; and (vi) tariff rates would be reduced gradually over a three year period starting in 1994-95 fiscal year to allow industry and labour markets time to adjust to the changes.

The policy-makers opted for a higher maximum tariff i.e., from 80 percent to 50 percent in three years with additional target of reducing the maximum duty rate to 35 percent in the next two years. The choice for a higher maximum tariff was based on several considerations. Firstly, the 50 percent maximum tariff rate structure would have a nearly revenue neutral imract. Secondly, it would allow for a more pronounced cascading of nominal tariff rates which would be likely to generate incentives for greater value-addition in production. Furthermore, various measures like the duty free imports of inputs for exportables would lead to a reduction in antiexport bias. Finally, efficiency gains would accrue from removal of numerous exemptions and reduction in the duty tiers, which would contribute towards more uniform effective protection.

The implementation and the degree of success in achieving the targets of 1993 Tariff Reform remained mixed. Some progress were made in implementing the Reform during September 1993 to November 1996. The tariff structure was simplified, and maximum tariffs were lowered from 80 to 65 percent (See Table 4). In 1994-95 two para-tariffs were merged with statutory rates while a third (flood relief surcharge) was abolished. The import surcharge levied at 10 percent was also abolished. Some progress was made during 1995-96 and 1996-97 in rationalising and reducing the number of SROs. Duty tiers remained numerous - there were 12 tiers of ad valorem duty rates ranging from zero to a maximum of 65 percent, with the exception of automobiles for which the maximum duty rate remained at 265 percent.

As a result of reduction in statutory rates the revenue mobilisation efforts of the government faltered and a policy reversals began to occur. To make-up for the revenue shortfall, a regulatory duty of 10 percent was levied on all imports subject to tariff rates up to 55 percent, while items on which tariff rate was 60 percent a regulatory duty at the rate of 5 percent was imposed. Furthermore, a withholding income tax of 5 percent on imports was also introduced. Sales tax was also raised from 15 percent to 18 percent.

The effectiveness of the tariff regime in general and reform process in particular was subverted and eroded in several ways. Firstly, the re-introduction of para-tariffs for fiscal consideration was a serious setback towards reducing anti- 
Table 4

Tariff Structure

\begin{tabular}{lc}
\hline Year & Maximum Tariff \\
\hline $1986-87$ & Rates (MGTR) \\
$1988-89$ & 225.0 \\
$1990-91$ & 125.0 \\
$1993-94$ & 95.0 \\
& 80.0 \\
$1994-95$ & {$[92.0]$} \\
$1995-96$ & 70.0 \\
$1996-97$ & 65.0 \\
$1997-98$ & 45.0 \\
\hline Source: Khan and & 45.0 \\
\hline
\end{tabular}

Source: Khan and Mahmood (1996) and the World Bank (1997).

Note: Number in square bracket is the MTR after merging the two para-tariffs.

export bias. Secondly, high and multiplicity of taxes were a major incentive to circumventing payment of duties. Thirdly, Pakistan's obligations to provide free access to transit trade to landlocked Afghanistan also complicated efforts at tariff reform. Finally, the 1993 Tariff Reform package was implemented at a time when Pakistan was facing large fiscal deficit. With increasing government expenditures and a need to reduce fiscal deficit, there was no room left for pursuing the tariff reform with vigour [World Bank (1997) and Khan (1997)].

Realising the importance of tariff reform in reducing anti-export bias the caretaker government (November 1996-February 1997) prepared a package of tariff reform with aims to bring about a transparent and cascading tariff regime bounded by low and internationally competitive tariff rates. The salient features of the tariff reform package of the caretaker government are: abolition of regulatory duty of 10 percent and 5 percent; withholding income tax rate of 5 percent is to be reduced to 2 percent; the maximum tariff rate should be reduced from 65 percent to 55 percent in 1997-98 and up to 35 percent by the year 2001; tariff structure will be cascaded downwards accordingly with the lowest rates for basic raw materials and the highest for finished goods; and reduction in duty slabs from 13 to 6 ; i.e. 10 percent, 15 percent, 20 percent, 25 percent, 30 percent and 35 percent in 1998-99.

The present government which took charge of the country's state of affairs on February 17, 1997 introduced a tariff reform package on March 28, 1997 which is more sharper than the one proposed by the caretaker regime. ${ }^{25}$ The objective of the present tariff reform package is to revive industrial production and export promotion. The salient features of the tariff reform are: the maximum tariff rate is reduced to 45

${ }^{25}$ See Ministry of Finance (1997) for details. 
percent from the previous level of 65 percent with the exception of automobiles; the 10 percent regulatory duty is abolished; the number of slabs in custom duties is reduced from 13 to 5 with rates of 10 percent, 15 percent, 25 percent, 35 percent, and 45 percent, the tariff rate on plant and machinery is standardised and brought down to 10 percent; the duties on primary raw materials, intermediate goods, and finished goods have been suitably cascaded with duties ranging from 10 percent to 45 percent; tariff rates on a wide range of smuggling-prone items are brought down to 10 percent and 25 percent; and to broaden the base of revenue an across-the-board minimum tariff of 10 percent is imposed with the exception of essential items like wheat, fertilisers and life saving drugs.

Notwithstanding significant tariff reform introduced in the 1990 s by successive governments the tariff structure continued to suffer from non-cascading rates in some cases [DRI-McGraw Hill (1997)]. Numerous exemptions and concessions have reduced the base of import duties with the result that most of the revenue is generated from a limited number of products. For example, only 62 percent of overall imports are dutiable, ranging from 50 percent for capital goods to 87 percent for raw material for capital goods [DRI-McGraw Hill (1997)]. The significance of exemptions and concessions can be gauged by the fact that the average rate of import duty, adjusted for exemptions/concessions was almost 35 percent as against the average import duty (all imports) of 20 percent (See Table 5).

Table 5

Average Rate of Import Duty with and without Exemptions/Concessions

(Percent)

\begin{tabular}{lcccccccc}
\hline & $1990-91$ & $1991-92$ & $1992-93$ & $1993-94$ & $1994-95$ & $1995-96$ & $1996-97$ \\
\hline $\begin{array}{l}\text { Average Import Duty (All Imports) } \\
\text { Average Import Duty }\end{array}$ & 23.0 & 17.9 & 20.8 & 20.6 & 21.6 & 21.6 & 19.6 \\
$\quad$ (Dutiable Imports) & 39.0 & 32.6 & 35.3 & 34.7 & 33.5 & 34.6 & N.A. \\
$\quad$ Consumer Goods & 38.0 & 36.9 & 40.8 & 38.2 & 43.0 & 45.8 & N.A. \\
$\quad$ Raw Material for Consumer & & & & & & & \\
$\quad$ Goods & 39.0 & 36.9 & 40.8 & 38.2 & 43.0 & 45.8 & N.A. \\
$\quad$ Raw Material for Capital Goods & 41.0 & 38.5 & 44.7 & 43.7 & 46.1 & 48.1 & N.A. \\
$\quad$ Capital Goods & 39.0 & 33.6 & 32.4 & 30.3 & 31.2 & 36.0 & N.A. \\
\hline
\end{tabular}

Source: Khan and Mahmood (1996) and World Bank (1997).

Beside trade liberalisation measures Pakistan also undertook export promotion measures to reduce anti-export bias in the trade regime. Most notable among these are the continuation of a flexible exchange rate policy. During 1990-91 to 1996-97, Pakistani rupee depreciated viz. US dollar by almost 58 percent. In addition to a flexible exchange rate policy several other measures were taken to mitigate the disadvantages that Pakistani exporters face due to the anti-export bias inherent in the country's import protection strategy. These include: (i) temporary import scheme; 
(ii) duty drawback scheme; (iii) refund of sales tax; (iv) export finance schemes; and (v) export credit guarantee scheme. ${ }^{26}$

Despite trade liberalisation and export promotion measures undertaken during the 1990s the existence of an import substitution bias is quite evident from Table 2. The ratios of two EERs (for imports and exports) are greater than unity implying a bias toward import substitution. Although the ratios are greater than unity, these nevertheless exhibit a declining trend which suggest that the trade liberalisation and export promotion measures were successful in reducing anti-export bias in the trade regime. Pakistan could have achieved more or less a neutral trade regime in the $1990 \mathrm{~s}$ as a result of the trade liberalisation and export promotion measures undertaken during the $1990 \mathrm{js}$ but the policy reversal forced by fiscal consideration that began at the end of 1994-95 fiscal year and lasted until March 1997 more than offset the gains. A significant reduction in tariff as well as in dispersion along with downward adjustment in Pakistani rupee are required to achieve neutrality in the trade regime.

\section{CONCLUDING REMARKS}

Pakistani exports over the last 50 years have grown at an average rate of 8.7 percent per annum in current dollar terms but exhibited divergent trend during these periods. When viewed against the experiences of many successful developing counties Pakistan's export performance has been lacklustre at best. Why Pakistan lagged behind in exploiting opportunities like many other Asian and other developing countries in expanding exports in general and manufactured exports in particular? This paper attempts to provide partial answer to the question by examining the trade liberalisation measures undertaken during the last 50 years. The main contribution of this paper is that it has summarised the trade liberalisation measures under taken during the last 50 years in one place.

A country's export performance is the mirror image of the trade regime it has followed. Fifty years of export performance clearly suggests that the policy regime in Pakistan has generally been biased against exports relative to the sale in home market despite significant trade liberalisation over the years. The extent of bias, nevertheless, has declined ever since Pakistan started implementing tariff reform and started focusing more on export expansion. Barriers to imports have been reduced drastically and import licensing has been completely abolished. The maximum tariff rate has been reduced from 225 percent to 45 percent over the last one decade; all para-tariffs have been merged into the statutory tariff regime, and all items are now importable with the exception of few on religious, health and security consideration. The number of slabs in custom duties is reduced from 13 to 6 with rates of zero percent, 10 percent, 15 percent, 25 percent, 35 percent and 45 percent. The duties on primary raw materials,

${ }^{26}$ These measures are discussed in Khan (1998). 
intermediate goods, and finished goods have been suitably cascaded with duties ranging from zero percent to 45 percent.

Despite various reforms introduced over the last one decade, the degree of insulation of Pakistan's economy has remained substantial. Pakistan's tariffs are still high and lacks transparency due to numerous exemptions and concessions extended under the special Regulatory Orders (SRO), with broad discretionary power enjoyed by the administration. As a result, the anti-export bias in the trade regime continues to persist despite significant trade liberalisation measures taken during the last one decade. More effort is, however, needed to make the trade regime neutral. In this connection the tariff reform process which was initiated in the late 1980s in general and in 1997-98 in particular, must continue. A level playing field for Pakistani exporters in international markets must be provided by giving them free access to imported inputs. In other words, inputs intended for value added exports should be zero-rated. If home sales continue to be more profitable relative to foreign sales, even FDI would come only to exploit the protected home market and not using Pakistan as production base for exports. Thus, even to attract FDI in export-oriented industries a neutral trade regime is must.

\section{REFERENCES}

ADB (1997) Emerging Asia: Changes and Challenges. Manila: Asian Development Bank. July.

Balassa, B. (1971) The Structure of Protection in Developing Countries. Baltimore: The Johns Hopkins University Press.

Balassa, B. (1981) The Newly-Industrialising Developing Countries After the Oil Crisis. Weltwirtschaftlisches Archir 117:1.

Balassa, B. (1985) Outward Orientation. The World Bank, July. (Discussion Paper No. DRD 148.)

Bhagwati, J. (1978) Anatomy and Consequences of Exchange Control Regimes.

Cambridge, Mass: Ballinger Publishing Company for National Bureau of Economic Research.

Bhagwati, J. (1987) Outward Orientation: Trade Issues. In V. Corbo, M. Goldstein and

M. Khan (eds) Growth-Oriented Adjustment Programmes. Washington, D.C.: International Monetary Fund and the World Bank.

Bhagwati, J. (1988) Export-Promoting Trade Strategy: Issues and Evidence. The World Bank Research Observer 3:1. January.

Chaudhry, Shahid A., and N. Hamid (1988) Pakistan. In Asian Development Bank (ed)

Foreign Trade Barriers and Export Growth. Manila: Asian Development Bank. September.

Chen, S., G. Datt, and M. Ravallion (1994) Is Poverty Increasing in the Developing World? Review of Income and Wealth 40:4.

Deininger, K., and L. Squire (1996) A New Dataset Measüring Income. World Bank Economic Review 10:3. 
DRI-McGraw Hill (1997) Tradelink Pakistan: An Agenda for Liberalising Trade and Promoting Exports. Study Completed for Pakistan 2010 Programme, October, Boston, Mass.

Edwards, S. (1993) Openness, Trade Liberalisation, and Growth in Developing Countries. Journal of Economic Literature 31: September.

Guisinger, S., and G. Scully (1991) Pakistan. In D. Papageorgiou, M. Michaely and A. M. Choksi (eds) Liberalising Foreign Trade: The Experience of Indonesia, Pakistan, and Sri Lanka, Vol. 5. Cambridge: Basil Blackwell.

Khan, Ashfaque H. (1997) Pakistan's Budgetary Imbalance: Full Bags, Empty Purses. Pakistan Banker 7:2, July-December.

Khan, Ashfaque H. (1998) Pakistan's Exports: Past Trends and Future Prospects. Manila: Asian Development Bank. June.

Khan, Ashfaque H., A. Malik, and L. Hasan (1995) Exports, Growth and Causality: An Application of Cointegration and Error-correction Modelling. The Pakistan Development Review 34:4.

Khan, Ashfaque H., and Najam-us-Saqib (1993) Exports and Economic Growth: The Pakistan Experience. International Economic Journal 7:3.

Khan, Ashfaque H., and Zafar Mahmood (1996) Emerging Global Trading Environment and Developing Asia: A Case Study of Pakistan. Manila: Asian Development Bank, November.

Krueger, Anne O. (1981) Export-led Industrial Growth-Reconsidered. In W. Hong and L. B. Krause (eds) Trade and Growth of the Advanced Developing Countries in the Pacific Basin. Seoul: Korean Development Institute.

Krueger, Anne O. (1984) Trade Policies in Developing Countries. In R. W. Jones and P. B. Kenen (eds) Handbook of International Economics 1. Amsterdam: NorthHolland.

Krueger, Anne O. (1994) The Political Economy of the Rent-Seeking Society. American Economic Review 64:3, June.

Krueger, Anne O. (1997) Trade Policy and Economic Development: How We Learn. American Economic Review 87:1, March.

Krueger, Anne O. (1997a) Factors Affecting Export Growth and Performance. Paper presented at the Commencement Workshop on Asian Exports: Past Trends and Future Prospects, Manila: Asian Development Bank, October 27.

Little, I. M. D., T. Scitovsky, and M. Scott (1970) Industry and Trade in Some Developing Countries: A Comparative Study. London: Oxford University Press.

Naoman, Akbar (1992) Liberalisation of Foreign Trade and International Competitiveness. In Anjum Nasim (ed) Financing Pakistan Development in the 1990s. Karachi: Oxford University Press.

Nognes, J. J., A. Obchowski, and L. A. Winters (1985) The Extent of Non-Fariff Barriers to Industrial Countries Imports. Washington, D.C.: The World Bank. 
Nurkse, R. (1961) Balanced and Unbalanced Growth. In G. Haberler and R. M. Stern (eds) Equilibrium and Growth in the World Economy, Economic Essays by Ragnar Nurkse. Harvard Economic Studies 118.

Pakistan, Government of (1997) Agenda for Economic Revival: An Overview. Islamabad: Ministry of Finance, September.

Prebisch, R. (1950) The Economic Development of Latin America and its Principal Problems. New York: United Nations Commission for Latin America.

Prebisch, R. (1959) International Trade and Payments in an Area of Coexistence: Commercial Policy in the Underdeveloped Countries. American Economic Review 49:2, June.

Reza, Sardel (1994) Policy Reform for Promoting Trade in Developing Countries. Asian Development Review 12:2.

Shah, S., A. Nasim, M. Ahmed, and U. Qureshi (1990) Pakistan. In Asian Development Bank (ed) Export Finance: Some Asian Example. Manila: Asian Development Bank. September.

World Bank (1997) Pakistan: Recent Developments, Policy Issues, and Agenda for Change. Islamabad: World Bank Resident Mission in Pakistan. 


\section{Comments}

It is over a decade now that Pakistan has been in the process of trade liberalisation. Personally, I feel that it is appropriate time to evaluate this experience in terms of its consequences on performance of the economy. On that count, I think, the author deserves credit for selecting this topic as a subject of his paper.

However, though attractive in topic, the paper is relatively poor in its treatment of the subject. The treatment is inadequate and at places incoherent.

The objective of the paper as mentioned by the author is "to document the trade liberalisation measures undertaken over the years with a view to reducing antiexport bias" (p. 3). But the paper allocates the first 8 pages to a conventional discussion on import substitution vs. export promotion which neither fits into the paper nor has any link with the remaining part of the paper, as none of the hypotheses made in the beginning has been tested empirically in the later part of the paper.

It seems that the author has added these pages for the paper to look like an analytical paper. There is nothing wrong with this aim. But, the problem is the analytical inadequacy of the paper. Let me cite two examples:

(i) Discussion on page 4 proposes the ratio of $E E R_{m}$ to $E E R_{x}$ as a measure of outward orientation. On page 8, it is claimed that "the East Asian countries are the ones that followed vigorously outward oriented strategy which helps to account for their better growth performance". But nowhere in the paper evidence to this claim has been provided by data on the falling said ratio in the case of East Asian countries. Because of this inadequacy, the paper fails to convince the readers that the falling ratio of $E E R_{m} / E E R_{x}$ was behind the high performance of East Asia.

(ii) When one applies the same measure of $E E R_{m} / E E R_{x}$ in the case of Pakistan, one fails to establish even an association between the growth and export performance on the one hand and falling ratio of $E E R_{m} / E E R_{x}$ on the other. According to the calculations made by the author in Table 2 , the anti-export bias did decline in Pakistan in the 90s. The average bias recorded at 28 percent in the 80 s was brought down through trade liberalisation to 20 percent in the $90 \mathrm{~s}$. Yet, export growth as reported in the paper declined from 8.5 percent per annum in the 80 s to 7.6 percent in the 90s. If one looks at export growth in real terms (which is the correct way), the decline in growth turns out to be more sharp, falling from 9.1 percent in the $80 \mathrm{~s}$ to 5.6 percent in the $90 \mathrm{~s}$. Similarly, if one looks at the large scale manufacturing growth, it also reflects a sharp decline; falling from 7.7 percent per annum in the 80 s to only 3.8 percent in the $90 \mathrm{~s}$. Against the backdrop of what has been presented in the paper, these are paradoxical results. Several question emerge in this context: 
(a) How valid trade liberalisation is as a measure of export orientation?

(b) Are there other complementary requirements for trade liberalisation to be successful in promoting exports? If yes, how important are those?

(c) If these requirements are difficult to be met in the medium term, is not trade liberalisation a sub-optimal (rather than the first best) strategy for export promotion?

(d) Has not Pakistan gone too fast in trade liberalisation, so that its negative impact on manufacturing via erosion in protection resulted in substantial reduction in exportable surplus?

It would have been in the fitness of things if all these questions had been addressed to, but the paper is totally devoid of such an effort. It only makes a categorical but un-substantiated claim about the relation between trade labralisation and high performance.

There is one more claim made by the author on page 4, stating that "export promotion strategy relates to trade incentives therefore the countries that follow this strategy not necessarily be outward oriented in their foreign investment policies". One fails to understand the logic behind this claim in the presence of empirical evidence available on the association between foreign investment and export promotion. If one looks at the experience of East Asian countries, one finds a phenomenal inflow of private capital flows during the last 20 years; around 8 percent of GDP equivalent in Thailand and Malaysia, and over 3 percent in Indonesia, Singapore and China. In fact, it is basically this evidence on the basis of which the analysts today treat export promotion and foreign private investment (especially DFI) as complementary.

The Planning Commission,

Shaukat Ali Islamabad. 